\title{
PENAMBAHAN KOLOM SEMEN TANAH SEBAGAI PERKUATAN TANAH DASAR EKSPANSIF SAAT KONDISI JENUH
}

\author{
Yudha Selviawan'), Bambang Setiawan²), Noegroho Djarwanti ${ }^{3)}$ \\ 1)Mahasiswa Program S1 Teknik Sipil Universitas Sebelas Maret \\ 2) 3) Staff Pengajar Program Studi Teknik Sipil, Universitas Sebelas Maret \\ Jalan Ir.Sutami No.36A Surakarta 57126.Telp.0271647069. Email :yudhaselviawan@gmail.com
}

\begin{abstract}
Abstrak
Banyak dijumpai struktur bangunan atau jalan yang belum waktunya diperbaiki sudah harus diperbaiki. Kerusakankerusakan pada jalan dan gedung, misalnya terangkat atau turunnya suatu pondasi, retak-retak dinding bangunan, dan bergelombangnya permukaan jalan, disebabkan oleh permasalahan pada tanah yang ada di bawah struktur suatu bangunan yang tidak hanya terbatas pada penurunannya (settlement) saja. Hal ini disebabkan, karena kurang memperhatikan kondisi tanah dasar (subgrade) yang kadang memiliki sifat ekspansif yaitu tanah yang mempunyai potensi pengembangan (swelling) yang tinggi. Menanggulangi hal tersebut serta mencegah terjadinya kerusakan yang berkelanjutan maka perlu dipilih metode penanggulangan yang paling tepat, yaitu salah satunya dengan metode kolom semen tanah. Penelitian ini dilakukan bertujuan untuk mengetahui berapa besar perpindahan vertikal yang terjadi. Pengujian dilakukan dengan melakukan pembasahan pada tanah tanpa perkuatan, dan tanah dengan kolom semen tanah. Hasil penelitian menunjukkan bahwa penambahan kolom semen tanah mampu mereduksi perpindahan vertikal subgrade sebesar 37,23\% hingga 74,68 \% dan gaya pengembangan tereduksi sebesar 25,00\% hingga 50,00\%.
\end{abstract}

Kata kunci : tanah ekspansif, subgrade, kolom semen tanah, perpindahan vertikal, gaya pengembangan.

\begin{abstract}
Structures or roads are many encountered that have not been fixed time has to be fixed. Damages to roads and buildings, such as the lifting or descent of a foundation, cracks in the walls of building, and suning road surfaces, are caused by problems with soil under the structure of a building that is not limited by its settlement. This is due to lack of attention about the condition of subgrade that sometimes has expansive characteristic which the soil has high swelling potential. Preventing the occurrence of continual damage, therefore it needs to be chosen the most exact method of handling, which one with soil cement column method. This research aimed to find out how much vertical displacement result. Testing was done by wetting the soil without strengthening, and soil with cement column. The results showed that the addition of soil cement column reduced the vertical displacement of subgrade by $37.23 \%$ to $74.68 \%$ and reduced the expansive force by $25.00 \%$ to $50.00 \%$.
\end{abstract}

Keywords: expansive soil, subgrade, soil cement column, vertical movement, expansive force

\section{PENDAHULUAN}

Permasalahan pada tanah yang ada di bawah struktur suatu bangunan dapat menyebabkan permasalahan pada jalan dan gedung, misalnya terangkat atau turunnya suatu pondasi, retak-retak dinding pada bangunan, dan bergelombangnya permukaan jalan. Permasalahan tanah ini tidak hanya terbatas pada penurunannya (settlement) saja tetapi mencakup secara menyeluruh, seperti adanya penyusutan dan pengembangan tanah.. Beberapa struktur bangunan telah mengalami kerusakan lebih dini, tetapi kerusakan berat tersebut tidak ada hubungannya dengan kondisi struktur, kualitas bahan, atau beban rencana dari struktur yang telah direncanakan melainkan akibat dari kondisi tanah dasar ekspansif yang kurang diperhatikan. Salah satu cara yang digunakan untuk menggulangi masalah tersebut adalah perbaikan tanah ekspansif dengan metode kolom semen tanah.

\section{TINJAUAN PUSTAKA}

Setiawan (2015) dalam penelitiannya menggunakan Sistem Cakar Ayam Modifikasi untuk mereduksi perpindahan vertikal pada tanah dasar ekspansif. Hasil penelitian menunjukan bahwa dengan menggunakan sistem CAM dapat mereduksi perpindahan vertikal akibat tanah dasar ekspansif mengembang, reduksi berkisar 59,46\% - 89,64\%. Cakar berfungsi sebagai angkur (paku) dan pemberat, sehingga pelat akan tertahan pada saat pengembangan tanah dasarnya. Berdasarkan penelitian yang sudah ditinjau, maka dilakukan percobaan untuk mengetahui perpindahan vertikal tanah dasar ekspansif ketika diberi perkuatan kolom semen tanah. Perkuatan kolom semen tanah diaplikasikan pada box berukuran $1 \mathrm{~m} \times 0,5 \mathrm{~m} \times 0,6 \mathrm{~m}$.

\section{DASAR TEORI}


Tanah berbutir halus memiliki luas permukaan (specific surface) yang cukup besar sehingga menyebabkan variasi kadar air akan mempengaruhi plastisitas tanah (Hardiyatmo 2014). Apabila specific surface membesar, maka harga batas cair (liquid limit) juga akan membesar.

Deep soil mixing (DSM) adalah teknologi perbaikan tanah di mana tanah dicampur dengan bahan seperti semen atau yang lainnya dengan tujuan perekat, biasanya dalam bentuk kering maupun basah. Bahan tersebut dimasukkan ke dalam pipa berongga, diputar dan diaduk dengan suatu alat seperti alat pemotong (Teng, 2000).

Dalam metode pelaksanaan deep soil mixing (DSM) terdapat beberapa pola yang sering diterapkan. Pola-pola tersebut diantaranya pola triangular pattern, pola square patterm, pola panels, pola blocks dan pola grid. Dalam penelitian kali ini, pola yang akan digunakan pada metode kolom semen tanah adalah square pattern.

\section{METODE PENELITIAN}

\section{Tahap Pendahuluan}

Penelitian pendahuluan dilakukan terhadap media tanah. Pengujian yang dilakukan terhadap tanah dimaksudkan untuk mengetahui parameter-parameter tanah dan untuk mengidentifikasi jenis tanah tersebut yang meliputi :

a. Pengujian kadar air (water content) untuk mengetahui kadar air sesuai aturan pengujian ASTM D 2216-92.

b. Pengujian specific gravity (Gs) untuk mengetahui berat jenis butiran tanah dengan acuan standar ASTM D 854-92.

c. Pengujian analisis butiran (grain size analysis), untuk mengetahui persentase susunan butir tanah sehingga dapat diketahui jenis tanah yang akan diuji sesuai aturan pengujian ASTM D 422-63.

d. Pengujian konsistensi (atterberg limit test) untuk mengetahui batas cair, batas plastis dan indeks plastisitas berdasarkan ASTM D 4318-95a.

\section{Tahap Penelitian Utama}

Tahap penelitian utama meliputi pekerjaan-pekerjaan antara lain sebagai berikut :

1.) Pembuatan sampel tanah pada bak pengujian yaitu melakukan persiapan kotak uji yang sudah diberi sekat sebagai pembatas antara tanah dasar tanpa perkuatan dan tanah dasar menggunakan perkuatan kolom semen tanah.

2.) Memasang dial dan perkuatan kolom semen tanah pada titik yang ditentukan. Sketsa perencenaan pemasangan kolom semen tanah seperti terlihat pada Gambar 1.

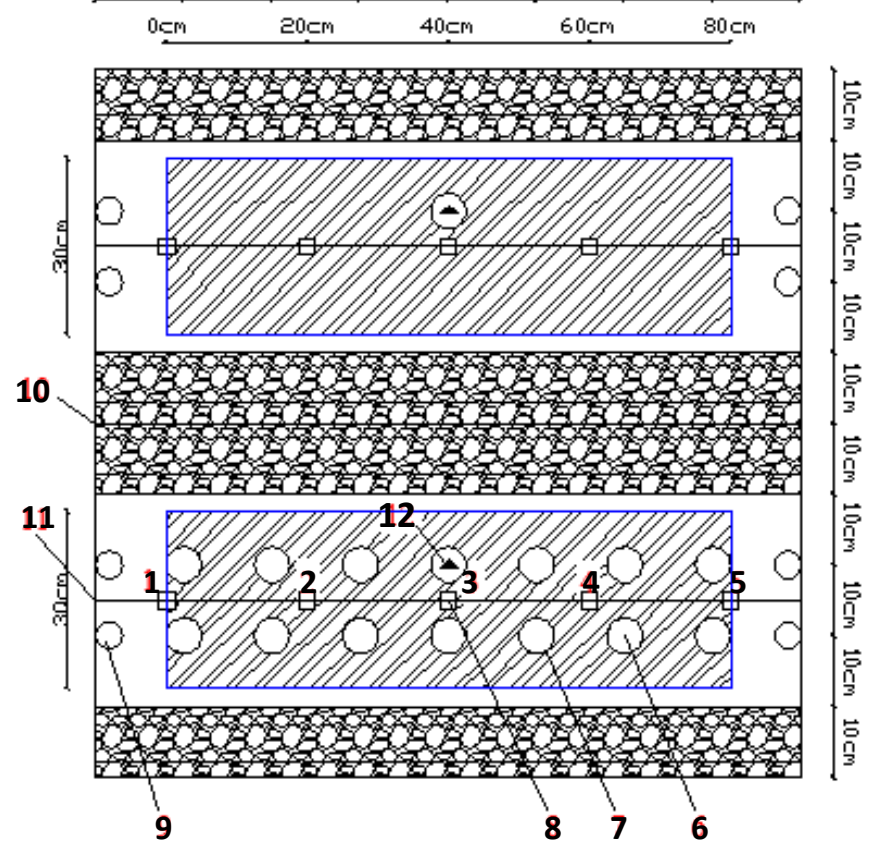

Gambar 1 Sketsa bak pengujian tampak atas

Keterangan :

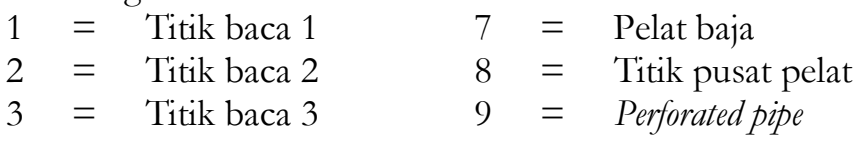




$\begin{array}{lllll}4 & =\text { Titik baca } 4 & 10 & = & \text { Sekat pembatas } \\ 5 & =\text { Titik baca } 5 & 11 & = & \text { Sumbu horisontal dial } \\ 6 & =\text { Kolom semen tanah } 12 & = & \text { Proving ring }\end{array}$

3.) Pembasahan dilakukan dengan menyiram permukaan tanah di sisi luar model pelat, serta melalui pipa drainase. Hal ini dilakukan serentak, dengan volume air yang telah ditentukan, pembasahan ini dilakukan setiap pagi dan sore.

\section{PENGUJIAN KLASIFIKASI TANAH}

Rekapitulasi penelitian parameter tanah yang dipakai sebagai media dalam pengujian pendahuluan tanah secara keseluruhan dapat dilihat pada Tabel 1 sebagai berikut :

Tabel 1 Hasil uji propertis tanah

\begin{tabular}{|l|l|c|c|}
\hline No. & \multicolumn{1}{|c|}{ Jenis Pengujian } & Satuan & Hasil \\
\hline 1. & Uji gradasi tanah & $\%$ & \\
& $\bullet \quad$ Kerikil & $\%$ & 0 \\
& $\bullet \quad$ Pasir & $\%$ & 9,82 \\
& $\bullet \quad$ Lanau dan lempung & & 90,18 \\
\hline 2. & Uji batas konsistensi tanah & \\
& $\bullet \quad$ Batas cair, LL & $\%$ & 70,84 \\
& $\bullet \quad$ Batas plastis, PL & $\%$ & 48,87 \\
& $\bullet \quad$ Indeks plastis, PI & $\%$ & 21,87 \\
\hline 3. & Kadar air awal & $\%$ & 68,11 \\
& Kadar air pasca pembasahan & $\%$ & 91,01 \\
\hline 4. & Berat spesifik, Gs & $\mathrm{kPa}$ & 2,656 \\
\hline 5. & Persentase mengembang & & 11,75 \\
& Tekanan mengembang & \\
\hline
\end{tabular}

Berdasarkan hasil pengujian parameter tanah yang di tampilkan pada Tabel 1, tanah yang digunakan dalam penelitian ini merupakan tanah lunak ekspansif dengan spesifikasi sebagai berikut :

a. Indeks plastisitas (PI)

Hasil nilai indeks plastisitas yang didapat setelah dilakukan pengujian batas konsistensi tanah adalah 21,87 $\%$, sehingga tanah tersebut dapat diklasifikasikan sebagai tanah ekspansif dengan potensi pengembangan tinggi.

b. Persen lolos saringan no. 200

Identifikasi tanah ekspansif berdasarkan pengujian saringan didapatkan nilai 90,18 \% yang lolos saringan no.200, sehingga dapat diklasifikasikan sebagai tanah ekspansif dengan derajat pengembangan tinggi.

c. Batas cair (LL)

Pengujian yang dilakukan untuk mengaklasifikasikan derajat pengembangan berdasarkan batas cair didapatkan nilai $70,84 \%$, maka tanah tersebut mempunyai derajat pengembangan yang sangat tinggi.

\section{ANALISIS DATA DAN PEMBAHASAN}

Pengjian yang dilakukan untuk mendapatkan nilai perpindahan vertikal baik tanah dasar tanpa perkuatan dan menggunakan perkuatan kolom semen tanah hanya selama 12 hari, karena perpindahan vertikal yang diamati hanya terhitung sejak tanah ekspansif berada dalam kondisi jenuh yang dimulai pada hari ke 19 hingga hari ke 30. Proses perpindahan vertikal rata-rata dari kelima dial yang dipasang pada masing-masing tanah dasar tanpa perkuatan dan dengan perkuatan kolom semen tanah selama 12 hari pembasahan disajikan dalam Gambar 2.

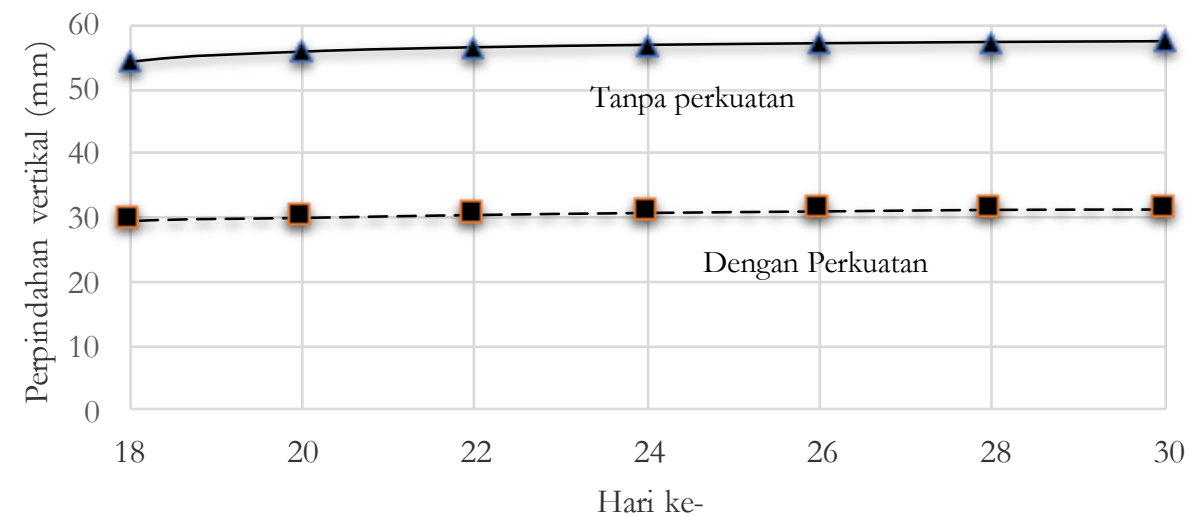


Gambar 2 Perpindahan vertikal rata-rata yang terjadi selama 12 hari pada tanah dasar tanpa perkuatan dan dengan perkuatan kolom semen tanah

Perpindahan vertikal yang terjadi pada Gambar 2 menunjukkan selama 12 hari pembasahan pada tanah dasar ekspansif tanpa perkuatan dan dengan perkuatan kolom semen tanah. Hari ke 28 pembasahan, perpindahan vertikal berada pada titik maksimal. Pengamatan pada hari berikutnya, besarnya perpindahan vertikal sangat kecil sekali hingga mendekati nol yang kemudian dinyatakan berhenti.

Gaya pengembangan yang diamati dimulai pada saat tanah sudah dibuat jenuh dahulu yang dimana tanah mulai jenuh air ketika pembasahan pada hari ke 18. Gaya pengembangan dihitung berdasarkan nilai baca pada dial gange yang terdapat pada proving ring dikalikan dengan faktor koreksi proving ring. Faktor koreksi yang digunakan pada proving ring yakni 2,4294 pound/div. Besarnya gaya pengembangan yang terjadi pada tanah dasar tanpa diberi perkuatan selama 12 hari pengamatan disajikan pada Tabel 2.

Tabel 2 Gaya pengembangan pada tanah dasar tanpa perkuatan

\begin{tabular}{|c|c|}
\hline $\begin{array}{c}\text { Hari } \\
\text { ke- }\end{array}$ & $\begin{array}{c}\text { Gaya pengembangan } \\
(\mathrm{kN})\end{array}$ \\
\hline 19 & 0,02 \\
\hline 21 & 0,06 \\
\hline 24 & 0,09 \\
\hline 27 & 0,13 \\
\hline 30 & 0,17 \\
\hline
\end{tabular}

Tabel 2 menunjukkan besarnya gaya pengembangan yang terjadi selama 12 hari pembasahan pada tanah dasar ekspansif tanpa perkuatan kolom semen tanah dengan interval 3 hari pengamatan.

Besarnya gaya pengembangan pada saat tanah dalam kondisi jenuh selama 12 hari pengamatan pada tanah dasar menggunakan perkuatan kolom semen tanah disajikan pada Tabel 3.

Tabel 3 Gaya pengembangan pada tanah dasar menggunakan perkuatan kolom semen tanah

\begin{tabular}{|c|c|}
\hline $\begin{array}{c}\text { Hari } \\
\text { ke- }\end{array}$ & $\begin{array}{c}\text { Gaya pengembangan } \\
(\mathrm{kN})\end{array}$ \\
\hline 19 & 0,01 \\
\hline 21 & 0,03 \\
\hline 24 & 0,07 \\
\hline 27 & 0,09 \\
\hline 30 & 0,09 \\
\hline
\end{tabular}

Tabel 3 menunjukkan besarnya gaya pengembangan yang diterima plat pada tanah dasar menggunakan perkuatan kolom semen tanah setelah 12 hari pembasahan. Besarnya penambahan gaya pengembangan yang terjadi pada saat tanah dalam kondisi jenuh hanya bernilai kecil sampai hari ke 30 pengamatan yang kemudian dinyatakan berhenti karena gaya pengembangannya yang sangat kecil hingga mendekati nol.

Pembacaan dilakukan setelah pembasahan dari tepi plat sebagai asumsi gambaran pengembangan tanah saat hujan yang dimulai dari bahu jalan. Besarnya gaya pengembangan yang terjadi pada tanah dasar tanpa perkuatan dan dengan perkuatan kolom semen tanah selama 12 hari pengamatan ditunjukan pada Gambar 3. 


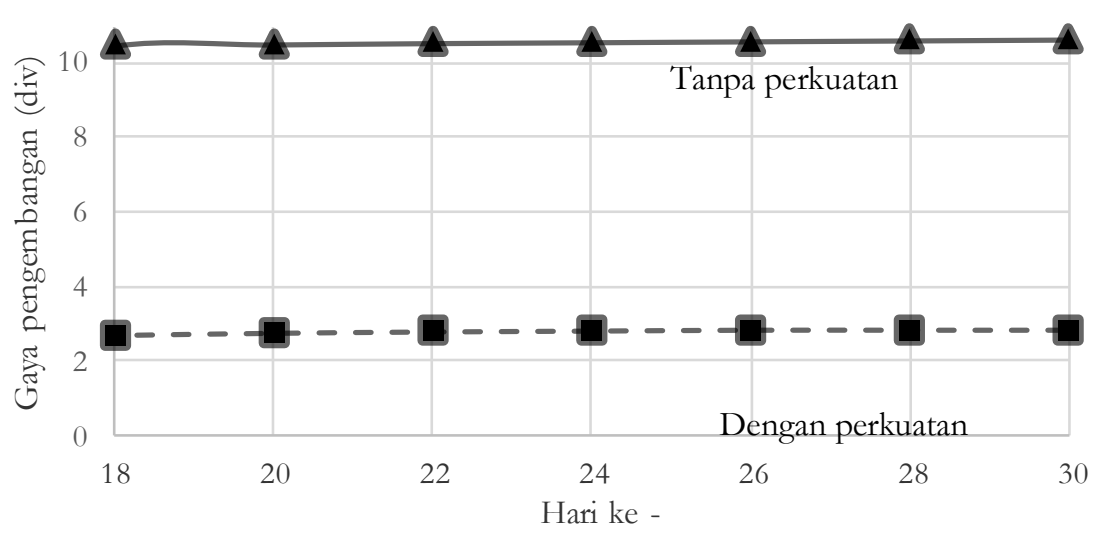

Gambar 3 Gaya pengembangan yang terjadi selama 12 hari pengamatan pada tanah dasar tanpa perkuatan kolom semen tanah

Gambar 3 menunjukkan besarnya gaya pengembangan yang terjadi selama 12 hari pembasahan pada tanah dasar ekspansif tanpa perkuatan kolom semen tanah. Besarnya gaya pengembangan terus mengalami kenaikan hingga hari ke 18 pengamatan. Gaya pengembangan mulai mengalami penurunan pada hari ke 19 yang menandakan tanah sudah mulai dalam kondisi jenuh dan seterusnya, kemudian dinyatakan berhenti.

Perpindahan vertikal yang terjadi setelah pembasahan pada tanah dasar tanpa perkuatan adalah 4,06 $\mathrm{mm} ; 4,11 \mathrm{~mm}$ di tepi kiri dan kanan plat. Pada tanah dasar menggunakan perkuatan kolom semen tanah, besarnya perpindahan vertikal yang terjadi setelah pembasahan adalah sebesar $2,53 \mathrm{~mm} ; 2,58 \mathrm{~mm}$ di tepi kiri dan kanan plat. Nilai perpindahan vertikal disajikan pada Tabel 4.

Tabel 4 Perpindahan vertikal saat pembasahan, tanah dasar tanpa perkuatan dan dengan perkuatan kolom semen tanah

\begin{tabular}{|c|c|c|c|c|c|c|c|c|c|c|c|}
\hline \multirow{3}{*}{ No. } & \multirow{3}{*}{ Hari ke- } & \multicolumn{10}{|c|}{ Perpindahan vertikal (mm) } \\
\hline & & \multicolumn{5}{|c|}{ Tanpa perkuatan, nomor titik baca } & \multicolumn{5}{|c|}{ Dengan perkuatan, nomor titik baca } \\
\hline & & 1 & 2 & 3 & 4 & 5 & 1 & 2 & 3 & 4 & 5 \\
\hline 1 & 19 & 1,33 & 1,32 & 0,2 & 1,25 & 1,42 & 0,42 & 0,2 & 0,03 & 0,17 & 0,4 \\
\hline 2 & 21 & 2,46 & 2,18 & 0,75 & 2,13 & 2,81 & 1,19 & 0,82 & 0,16 & 0,79 & 1,15 \\
\hline 3 & 24 & 3,27 & 2,74 & 1,2 & 2,7 & 3,44 & 1,84 & 1,34 & 0,22 & 1,29 & 1,81 \\
\hline 4 & 27 & 3,82 & 3,12 & 1,46 & 3,12 & 3,9 & 2,31 & 1,74 & 0,32 & 1,68 & 2,39 \\
\hline 5 & 30 & 4,06 & 3,26 & 1,54 & 3,26 & 4,11 & 2,53 & 1,89 & 0,39 & 1,8 & 2,58 \\
\hline
\end{tabular}

Gambar 4 menunjukan kurva saat proses pembasahan tanah dasar tanpa perkuatan. Tampak plat melengkung membentuk pola setengah lingkaran. Terdapat perbedaan tinggi vertikal yang signifikan apabila dibandingkan dengan tanah dasar yang sudah diberi perkuatan kolom semen tanah. Tampak pada Gambar 5 bahwa perkuatan kolom semen tanah mereduksi besarnya perpindahan vertikal.

$12 \stackrel{3}{2} \quad 3$




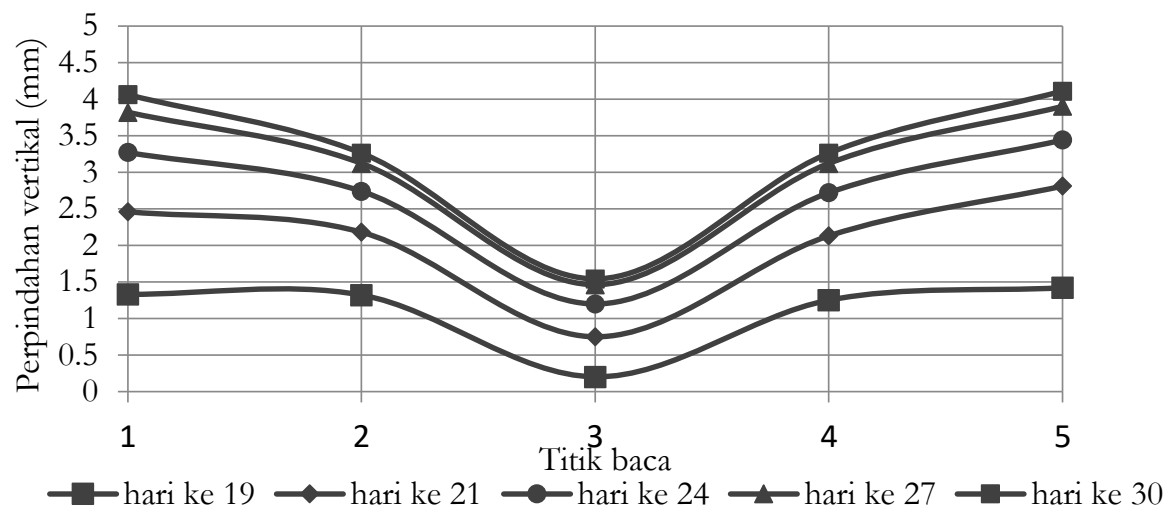

Gambar 4 Perpindahan vertikal tanah dasar tanpa perkuatan

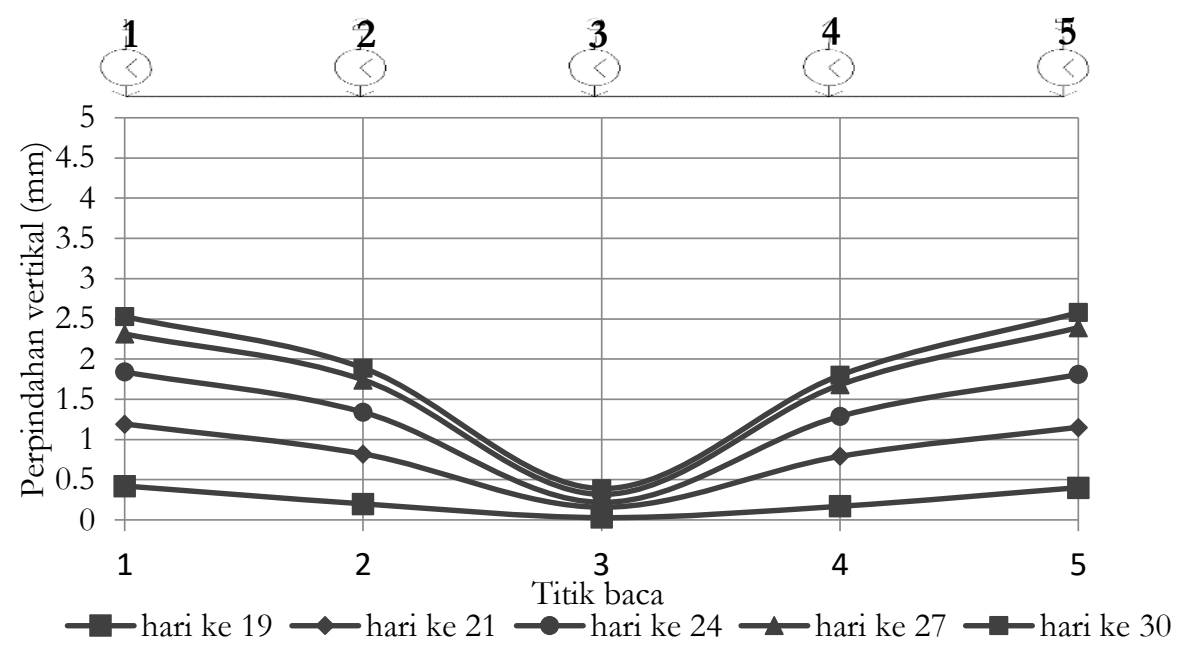

Gambar 5 Perpindahan vertikal tanah dasar dengan perkuatan kolom semen tanah

Nilai perpindahan vertikal pada akhir pengamatan hari ke - 30 disajikan dalam Tabel 5, dari hasil uji tersebut dapat disimpulkan, bahwa dengan penambahan kolom semen tanah pada tanah dasar ekspansif dapat mereduksi gerakan ke atas plat baja dengan reduksi sebesar 37,23 \% hingga 74,68\%.

Tabel 5 Reduksi perpindahan vertikal

\begin{tabular}{|c|c|c|c|}
\hline \multirow{2}{*}{ No. } & \multicolumn{2}{|c|}{ Perpindahan vertikal (mm) } & Reduksi \\
\cline { 2 - 3 } & Tanpa perkuatan & Kolom semen tanah & $(\%)$ \\
\hline 1 & 4,06 & 2,53 & 37,68 \\
\hline 2 & 3,26 & 1,89 & 42,02 \\
\hline 3 & 1,54 & 0,39 & 74,68 \\
\hline 4 & 3,26 & 1,8 & 44,79 \\
\hline 5 & 4,11 & 2,58 & 37,23 \\
\hline
\end{tabular}

Perbandingan gaya pengembangan pada kedua sampel menunjukkan perubahan yang signifikan. Tanah dasar yang sudah diberi perkuatan kolom semen tanah mampu menahan gaya ke atas tanah dasar sehingga berpengaruh juga pada perpindahan vertikal tanah dasar. Besarnya reduksi gaya pengembangan setelah tanah dasar diberi perkuatan kolom semen tanah dapat dilihat pada Tabel 6.

Tabel 6 Reduksi gaya pengembangan

\begin{tabular}{|c|c|c|c|}
\hline \multirow{2}{*}{$\begin{array}{c}\text { Hari } \\
\text { ke- }\end{array}$} & \multicolumn{2}{|c|}{ Gaya pengembangan $(\mathrm{kN})$} & \multirow{2}{*}{$\begin{array}{c}\text { Reduksi } \\
(\%)\end{array}$} \\
\hline 19 & Tanpa perkuatan & Kolom semen tanah & 50,00 \\
\hline
\end{tabular}




\begin{tabular}{|l|l|l|l|}
\hline 21 & 0,06 & 0,03 & 40,00 \\
\hline 24 & 0,09 & 0,07 & 25,00 \\
\hline 27 & 0,13 & 0,09 & 27,27 \\
\hline 30 & 0,17 & 0,09 & 42,85 \\
\hline
\end{tabular}

Reduksi gaya pengembangan terjadi setelah tanah diberi perkuatan kolom semen tanah .Berdasarkan hasil uji tersebut dapat disimpulkan, bahwa dengan penambahan kolom semen tanah pada tanah dasar ekspansif dalam kondisi jenuh dapat mereduksi gaya ke atas plat baja dengan reduksi sebesar 25,00 \% hingga 50,00 \%.

\section{KESIMPULAN}

1. Perpindahan vertikal yang terjadi setelah pembasahan pada tanah dasar tanpa perkuatan didapatkan 4,06 $\mathrm{mm} ; 4,11 \mathrm{~mm}$ di tepi kiri dan kanan plat

2. Perpindahan vertikal yang terjadi setelah pembasahan pada tanah dasar dengan perkuatan kolom semen tanah didapatkan 2,53 $\mathrm{mm} ; 2,58 \mathrm{~mm}$ di tepi kiri dan kanan plat.

3. Penambahan kolom semen tanah pada tanah dasar ekspansif dapat mereduksi gerakan ke atas plat baja dengan reduksi sekitar $37 \%$.

4. Penambahan perkuatan tanah dasar berupa kolom semen tanah juga mereduksi besarnya gaya pengembangan tanah dasar ekspansif, reduksi berkisar 25,00\% hingga 50,00\%

\section{REFERENSI}

Anonim, 1997, Annual Book of ASTM Standard. USA.

Hadiyana, R., 2016, "Penambahan Tiang Kayu Sebagai Perkuatan Pada Tanah Dasar (Subgrade) Lunak", Skripsi, Program Studi Teknik Sipil Universitas Sebelas Maret, Surakarta.

Hardiyatmo, H.C., 1992 dan 2006, Mekanika Tanah 1, Yogyakarta: Gajah Mada University Press.

Hardyatmo, H.C., 2014, Tanah Ekspansif Permasalahan dan Penanganan, Yogyakarta : Gadjah Mada University Press.

Setiawan, B, 2015, "Perilaku Sistem Cakar Ayam Modifikasi Pada Tanah Ekspansif”, Disertasi, Program Studi Teknik Sipil dan Lingkungan. Universitas Gadjah Mada, Yogyakarta.

Teng, P., 2000, An Introduction to the Deep Soil Mixing Methods as Used in Geotehcnical Applications. Publication No. FHWA -RD -99-138 